Isabella Hermann

Berlin-Brandenburg Academy of Sciences and Humanities

\title{
Boundaries and Otherness in Science Fiction: We Cannot Escape the Human Condition
}

\section{ABSTRACT}

The article explores the construction of boundaries, alterity and otherness in modern science-fiction (SF) films. Boundaries, understood as real state borders, territoriality and sovereignty, as well as the construction of the other beyond an imagined border and delimited space, have a significant meaning in the dystopian settings of SF. Even though SF topics are not bound to the contemporary environment, be it of a historical, technical or ethical nature, they do relate to the present-day world and transcend our well-known problems. Therefore, SF offers a pronounced discourse about current social challenges under extreme conditions such as future technological leaps, encounters with the alien other or the end of the world. At the same time the genre enables us to play through future challenges that might really happen. Films like Equilibrium (2002), Code 46 (2003), Children of Men (2006) and District 9 (2009) show that in freely constructed cinematic settings we are not only unable to escape from our border conflicts, but quite the contrary, we take them everywhere with us, even to an alternative present or into the future, where new precarious situations of otherness are constructed.

Keywords: international relations, emotions, body politics, alien encounter, world state. 


\section{INTRODUCTION}

Science-fiction (SF) films are so fascinating because they show us in a comparatively short time a technically advanced possible future that serves as a mirror for our desires and anxieties. What makes SF filmsand the whole SF genre in general-interesting for action enthusiasts, tech nerds and social researchers alike is the fact that they are neither formally nor conceptually bound to the (technological) limitations of our real world but offer a potential alternative. However, the authors and directors of SF, in addition to the scientists and experts whom they ask for information and advice, are, naturally, part of our real world. This means that problematics being discussed in SF always relate to contemporary human experiences while transferring them to extreme, alternative settings. Such contexts as future technological leaps, encounters with the alien other, or the end of the world open up a discourse where both current and timeless social-political challenges emerge as if viewed under a magnifying glass. One important recurring topic in SF is that of geographical, political and social boundaries, be it state borders, territoriality and sovereignty in general, as well as the other beyond an imagined border and delimited space. The construction of borders, new frontiers and otherness and their political implications can be seen very clearly in Star Trek: Original Series, as well as Star Trek: The Next Generation, where it is precisely the task of the crew of the Spaceship Enterprise to explore "new frontiers" (Buzan; Neumann).

Thus, dealing with borders and otherness-physically existent or constructed and imagined-are crucial topics in SF films echoing how we think about ourselves and our society. I call this discourse on socialpolitical challenges which is opened up by the genre boundary management, with the boundary being precisely the area where material, social, ethical or ideological borders overlap and thus have to be dealt with.

Referring to four modern, dissimilar and rather non-commercial SF movies, I will show how these films try to manage old and new boundaries and how they are connected to our current reality. As such, the paper argues that we are not only unable to escape from our boundary conflicts, but, quite the contrary, that we also carry them everywhere with us, even to an alternative present or to the future, and construct precarious new situations of restriction and otherness. We are in an ongoing process of boundary management. The paper is divided into three sections. In the first, I will elucidate the rather descriptive research approach which explores $\mathrm{SF}$ as a representation of reality, in addition to what I understand by modern SF. The second and main section deals with the dominant topics of boundary-management by means of an individual analysis of 
the SF films Equilibrium (2002), Code 46 (2003), Children of Men (2006) and District 9 (2009). Finally, the conclusion will summarize the findings, arguing that $\mathrm{SF}$ can be seen as a way to be inspired to discuss and solve future problems.

\section{SF AND POLITICAL ANALYsis}

There are many ways to analyze SF. Generally, SF can be defined as a genre where some scientific technological progress has taken place which then exerts influence over our social and political life. Therefore, SF films are often set in the future. However, the real or merely imagined scientific plausibility differentiates SF from the genre of fantasy which is located in a rather magical world or universe without necessarily having a connection to our current reality. In SF, the future technological innovations enable the audience in general, and social researchers in particular, to critically examine and think through social-political problematics that are at the point of occurring or have not happened yet but that might happen in the future (Kiersey and Neumann 7). Therefore, SF is often inherently political since social and political problematics are not only dealt with implicitly as side-effects of an action-laden story, but the genre also "concerns itself quite self-consciously with political issues future and present” (Weldes 10).

As part of popular culture, one might view SF as a mirror of reality, "as evidence about dominant norms, ideas, identities, or beliefs in a particular state, society or region" (Nexon and Neumann 13). This means that I make a distinction here between "in-world" and "in-show"; thus between the "real world" and what happens in the movies (Kiersey and Neumann 5-10). My claim is then to show how the films analyzed deal with border and boundary problematics with the aim of finding out more about the conditions of our society and how we are trapped in them. Consequently, my interest is to show how these films represent and transcend current real-world problematics of borders and boundaries.

In order to show a variety of different boundary constructions, the article deals with four contemporary SF films made after 2000. The date of 2000 was chosen for two reasons. Firstly, the magical date of 2000 is in itself an indicator of modernity and SF having finally come true. Since the setting of many SF films of the $20^{\text {th }}$ century takes place after 2000, this date is inherently connected with a move into the modern age or a "jump into the future." The most prominent example is Kubrick's 2001: A Space Odyssey from 1968, where the title already indicates a modern and technologically advanced world right after the 
turn of the millennium. Secondly, the 9/11 attacks of 2001 meant a real change of political paradigm, exposing the vulnerability of the U.S. and the Western liberal democratic model. Apparently Fukuyama's End of History (1992) was only a dream and it seems that we might rather head towards Huntington's Clash of Civilizations (1996). Congruent with the realization that the turn towards Western liberal democracy was not the desired progress of global society, a shift took place from the fun patriotic U.S. movies of the 1990s, such as Stargate (USA/France 1994), Independence Day (USA 1996), Men in Black (USA 1997), or Armageddon (USA 1998), to rather dire and/or critical ones after 2000, including Minority Report (USA 2002), I, Robot (USA 2004), The Island (USA 2005), I Am Legend (USA 2007), The Day the Earth Stood Still (USA 2008), Ender's Game (USA 2013), Elysium (USA 2013), and Snow Piercer (USA/South Korea 2013) —not to mention the new version of the TV series Battlestar Galactica (Canada 2004-09). ${ }^{1}$ While serious SF films were also made in the 1990s, and lighter ones after 2000, a certain trend is nonetheless clearly observable.

Being aware that the analysis of films contains an entire methodological toolkit of its own, I concentrate here on the text and narrative of the films in order to establish their connections to current political problematics (Kuhn, Alien Zone 9). SF is of course defined as a film genre also by aesthetics of destruction and disaster (Sontag), as well as by technical innovations in terms of special effects (Kuhn, Alien Zone II 1-8). However, this is of rather less importance for the sake of this contribution. I do not engage in a film analysis but make the point that SF deals with everlasting political problematics.

\section{Boundary Issues in Modern SF}

For the analysis, I chose the films Equilibrium (USA 2002, dir. Kurt Wimmer), Code 46 (UK 2003, dir. Michael Winterbottom), Children of Men (USA/UK 2006, dir. Alfonso Cuarón) and District 9 (USA/New Zealand/ Canada/South Africa 2009, dir. Neill Blomkamp). They were selected for three reasons: firstly, because they self-consciously deal with political issues, preserving the researcher from overinterpretation; secondly, because they all broach very different issues of boundary management, demonstrating

1 This also includes the new film versions of comics presenting the heroes as torn and vulnerable individuals like in X-Men (USA 2000), Spider-Man (USA 2002), Daredevil (USA 2003), Hellboy (USA 2004), Batman Begins (USA 2005) or Iron Man (USA 2008), and their numerous sequels. 
the whole variety of thought experiments that SF can provide; and thirdly, because all of them have a clear and comprehensible link to our real world and current problems, in spite of the diversity of boundary management topics.

Quite unsurprisingly, most of the SF films produced post-2000 are dystopias. Generally, a dystopia signifies a negative and alarming political vision understood as the opposite of Thomas More's utopia which has become proverbial today for a perfect but unattainable social-political community (see Arnswald and Schütt). Dystopias are generally designed as autocratic or dictatorial regimes being characterized by open, or rather concealed, authoritarian or totalitarian traits. Therefore, dystopias in science fiction are a way to critically analyze and question negative real or potential distortions of our political systems. Embedded in dystopian settings are the political problematics of body politics and how to develop a common human identity or become a world state respectively. The former term-body politics-refers to the policies and practices of how the political/social elite rules over the human body, thus indicating a battle between individual and public control over ourselves and physical integrity (Grosz). This comprises discussions about birth control and abortion, cloning, the use of drugs, viruses, or implants, as well as the development of cyborgs, androids and artificial intelligence. A good example, which will not feature in this article, is the 2009 film Moon, which deals with the fundamental ethical difficulties, including the right to self-determination, involved in cloning.

The other thematic centers include discussions about the possibilities of founding a world state and common human identity. According to social psychological research we are always in need of an Other in order to define our own social and group identity (Tajfel; Tajfel and Turner). The boundary between in-group and out-group can be set in two different ways, namely in the form of enmity or competition. Concerning the first, the in-group identity is strengthened by defining the out-group as a common menace to be collectively disdained or destroyed. In the two Independence Day films, humanity was united across state, cultural and religious borders by the joint fight against the alien menace. Concerning the second, the othering process happens in the more constructive manner of a competition in which one group might be the winner or the best according to certain standards. The out-group might even be perceived as ideal to follow suit. In Star Trek, humanity only developed a common identity after contact with the technologically and socially advanced Vulcans, an alien race having overcome war and violence. As such, the in-group identity is always constituted and strengthened by projecting a certain image of the outgroup, be it positive or negative. 


\section{EQUILIBRIUM}

The film Equilibrium is set in a future world which has been devastated by World War III. From the ruins of war the totalitarian state Libria has emerged, where the people are prohibited by the state/government from engaging in any cultural activity such as art or music which might bear the danger of causing emotions. Moreover, people are obliged to take a substance in order to suppress emotional reactions, which is a clear case of severe body control by state authorities. Conformity with the system is assured by a sophisticated monitoring mechanism headed by a dictator called "Father,", a reference to George Orwell's "Big Brother" in 1984. Nonetheless, an underground resistance group has formed whose members-while pretending to take the substance-secretly indulge their emotions in the form of collecting art, listening to music, dancing, and falling in love of course. The story ends up in a huge showdown in the monumental buildings of the totalitarian regime.

Of major political relevance in the film is the postulated contrast between rational and irrational behavior. Obviously, the state government in Equilibrium considers emotions as detrimental to rational thinking and decision-making, having even caused World War III and endangering international peace. However, there is in fact no need to go as far as evoking an ominous World War III. We know from World War I and II and many other violent historical conflicts that misguided emotions, such as excessive nationalism and chauvinism, have been identified as one of the key instigators of violence and suffering (Hobsbawn). For the sake of peace it may therefore seem necessary to suppress those anarchic features of human biology. However, in addition to many daily joys, by blocking emotions and destroying all material that might generate them we lose not only our negative incentives to start war but all our other cultural achievements as well. So as in a Greek tragedy we paradoxically lose what we want to preserve by trying to preserve it: our humanity.

Interestingly enough, according to social psychological common sense knowledge, social life cannot work without emotions (Stein). Along with other psychological and cognitive facts, emotions contribute to the making of good and bad decisions, or "rational" and "irrational" ones. But it is not emotions per se that distract the human being from coming to valid decisions. Rather, it is the other way around: without emotions there would be no decisions at all. However, in political science and above all in International Relations when analyzing the behavior of decisionmakers, emotions were and continue to be explored not as a natural part of social life but rather as factors to explain a deviation from rationalitynotwithstanding that such a rational baseline needs to be defined in the first 
place. ${ }^{2}$ Thus, while on the one side rational choice theorists try to come to a predictive power by using rational assumptions, psychologists might even find it absurd that anyone would assume that individuals are rational (McDermott 12-13). This has only started to change within the last 15 years or so with the so-called emotional turn in International Relations.

Hence, in relation to managing the boundary between "rationality" and "irrationality" - or let us say between good or bad decisions on the political level-emotions can contribute to either. Equilibrium makes it apparent that, when it comes to social peace, the problem of Libria is not emotions but rather the systems that are trying to oppress emotions, namely the dictatorial regime. To avoid a World War III and a negative influence of emotions on politics as has happened in the setting of the film we need strong political institutions and protective mechanisms. This is the boundary between good and bad political decisions and not emotions. Against this background, Equilibrium, made in 2002, must be seen as a critical forerunner of the importance of the topic for the political sphere. After all, the "Father" dictator is of course not taking the emotionsuppressing drug_-otherwise he probably would not have been capable of making the "rational" decisions necessary to govern his country Libria.

\section{CODE 46}

Like Equilibrium, Code 46 also imagines a frightening future with a totalitarian government. However, here this is presented not in the form of a stylish action spectacle but as a poetic science-fiction romance with intense images and music. However, the dystopian setting has quite a different character since it is not as obvious as in Equilibrium but far more implicit, if not even unknowable. The world presented at the beginning of Code 46 might even look rather positive, as a dream of many political scientists, international analysts and global activists come true: the world is organized as a quasi-world-state with a global supranational authority. People are living independently of ethnic or cultural affiliation all over the globe. The movie is shot in English but there are permanently and naturally embedded all kinds of references to Spanish, French, Italian, Arabic and Farsi which are well understood by everyone in this future world. The movie mainly takes place in the "megacity" Shanghai, which has not much in common with the Chinese city as we know it, but serves rather as a metaphor for a global melting pot resulting in a common human identity. How this global rapprochement has taken place is not stated openly, yet the audience

2 This is criticized by Mercer (79), among others. 
understands that scientific leaps in the fields of reproduction technologies apparently occurred and that cloning played a major part. According to the logic of the film, this technological advancement obliges the state authorities to regulate the global community with diverse body-politics. The world is ruled by certain codes restricting self-determination and one's own physical integrity. Since obviously there are so many clones, couples planning to have a child need to get official approval for their wish so as to preclude potential incest. If there is some familial relation between the future parents then the pregnancy will not only be terminated but the parents will also be treated with memory liquidation or infection with personalized viruses in order to avoid further sexual contact between them.

Other alarming facts are the damaged ecosystem. People are prohibited to go out during daytime to avoid solar irradiation. Even more, travels are regulated by restrictive visa policies to protect people from going to regions where they lack immunity against certain diseases. A young researcher dies after being infected with a deadly virus traveling with a counterfeit visa to "Delhi" because he was not issued a legal one. Visas are issued in a centralized way by the authority "Sphinx" which literally indicates two facts: firstly that, like the mythological sphinx, the official authorities know a lot more about every individual person than the person themselves; secondly, that by keeping this information the official authorities secretly exert some arcane power over the citizens with the aim of controlling them. In this sense, Code 46 appears to be more disquieting than Equilibrium, because the stark regulations of the global community do not attract suspicion at first sight. The protagonists - two lovers who will violate code 46can hang out in bars and clubs and have fun the entire night in Shanghai without trouble. Moreover, the regulations seem necessary to protect the humans from their own genetic incompatibilities and deficiencies. Yet the means are questionable, stretching from surveillance to surgical procedures carried out without the knowledge or even the approval of the person concerned.

The film shows how the boundaries of our international system are not lifted but rather shifted from being state borders to being new hyper-individual ones defined by our genome. The main characteristic of identifying a person is not the national passport anymore as it is now, but the genes. The places where people are allowed to travel are no longer prescribed by the passport, but by a superior authority based on individual characteristics of the body. Even having children needs to be approved officially since a couple might be related unknowingly —an aggravation of Western laws according to which brothers and sisters are not allowed to have children. In Code 46, national politics as the social-political organization by the state was thus not substituted for a liberal global hierarchy as desired 
but for a restrictive globalized body politics control mechanism. However, even worse, participation in this globalized world is again not open to all people since there is another new boundary of the ones living inside the megacities and the marginalized and excluded living outside of them in slums and dangerous daylight without chances of social mobility. The film demonstrates that, even if restrictions given by nationality and passport might be overcome, humans always create new precarious constraints, one between inside and outside, and one defined by the genome.

\section{ChildREN OF MEN}

Children of Men is also a dystopia; however, in contrast to the two films discussed above, it is characterized by a strong "reality fiction" element locating the story within a quite realistic setting. Thus, after having accepted an initial rare event paving the way for extreme circumstances, the plot advances in comprehensible ways, yet allowing our current political and social problems to clearly resonate. The reality fiction element is strengthened by the use of long and complex tracking shots giving the impression that we are in the scene as a participant, not as a mere spectator. ${ }^{3}$

The movie is set in the near future England of 2027. The initial event starting the storyline is that 20 years ago humanity was overcome by a global epidemic of infertility reminiscent of a biblical plague. The film kicks off with the bad news that 18 year-old "Baby Diego"-until then the youngest person on earth - has been shot dead by a fanatical fan. Following the camera from the news-monitor of a fast-food-restaurant to the streets of London demonstrates that major technological leaps have not occurred, so life as we know it has not changed fundamentally. However, the city looks extremely dilapidated. Clearly, London is no longer a popular tourist destination. The global menace of infertility has not united humanity; quite the contrary, it was the final straw in the collapse of any cooperation on the global level.

The permanent threat of terrorist acts by international Islamic fundamentalists or domestic resistance groups, and the danger of ecological decline, as well as a demographic development working towards an extremely ageing population-which authorities try to manage by means of legal suicide pills for the elderly-lead to ongoing riots and revolts. Great Britain finds itself in a continuous state of emergency, but it still seems to be the only more or less functioning state left. This causes

3 This was further elaborated by director Alfonso Cuarón with his Academy Award-winning Gravity. 
enormous migration fluxes to the country which the government tries to combat with vast reception centers. All the scenes are directly reminiscent of grievances of today and indeed even more in the year 2018 than when the film was released in 2006: first and foremost, the sealing off of Western states from illegal immigrants with Great Britain's decision to leave the European Union made in the 2016 referendum. But there are also links to the detention camp in Guantánamo and the Abu Ghraib prison scandal.

The scenario legitimizes, or at least gives rise to a repressive "police state" apparatus desperately trying to maintain law and order: the last state helplessly fights for internal and external sovereignty to preserve the borders as we know them. The film suggests that when it comes to a comprehensive international crisis the boundary being managed might actually be reduced to a mere state border. Obviously, there is no functioning inter- or supranational cooperation anymore; rather, each state is fighting for its own survival. All other ethical and moral values are subordinated to that objective. The initial assumption of neorealism that the international anarchical order determines a self-help-system where international cooperation is only of temporary duration has come true (Waltz). Children of Men unmasks all our existing international agreements as mere illusions belying the true mechanisms of our system: the war of all against all.

But perhaps there is hope for humanity, since in the end there is a pregnant woman. With her dark skin the movie-being full of all kinds of historical, political and religious references-makes the point that Africa was in fact the cradle of humanity. The West might thus reassess its restrictive immigration policies. She makes her way to the "Human Project," a research facility in the Azores which is trying to find a treatment for global infertility, and which is apparently the last remnant of international cooperation.

\section{DISTRICT 9}

Like Children of Men, District 9 is an example of reality fiction. However, the plot is not set in the future but takes place in an alternative present. Again, a rather odd initial event allows for a new perspective through which to think about our political order: the classical alien encounter. The authentic appearance of the film is enforced by the use of hand cameras making the watcher feel embedded as if following a documentary rather than a fiction film.

The story begins in the year 1982 when an alien spaceship comes down to earth and, after having suffered some technical defect, ends up hovering right above the city of Johannesburg in South Africa. After a while the 
humans decide to enter the spaceship and find thousands of injured, sick and frightened alien creatures. Like humans, they possess four extremities and walk upright, but they are much bigger and have an appearance between an insect and a reptile; around their mouths they have even fish-like barbells. This kind of perverse and distorted proximity to human appearance is quite unsightly from a human viewpoint and makes it easier to segregate them. Nobody knows what to do with the large number of uninvited, but intelligent, guests, so the "prawns"—as they are pejoratively calledare settled in the provisional "District 9" camp. After this prologue the actual storyline takes place more than 25 years later in the then present of 2009. The aliens still living in District 9, which has turned into a neglected and precarious ghetto-like place, eke out a miserable and degenerated existence. Their life is marked by the criminal and black market activities of South Africans who exploit their desperate situation. Order is maintained more or less by "Multinational United" (MNU), a not further specified private organization/corporation permeated by xenophobic staff. They are preparing a resettlement of the aliens to District 10 which is located 200 kilometers outside of Johannesburg. Naturally, MNU pursues more lucrative objectives by trying to access the modern weapon technologies of the aliens which only work in combination with their alien DNA. ${ }^{4}$

The parallels being drawn with the help of the extreme image of the alien other are apparent: the ruthless MNU reminds us of the highly criticized private security providers engaged by the U.S. during the course of the 2003 Iraq War and not abiding by international law. Obviously, in the movie, there is neither an international outcry nor an inclusive international organization taking care of this problem. Has the UN been substituted for an agency without scruples? Or is it simply uninterested, powerless or riveted by the disagreement of its members? In any case this makes us think about the fatal inactiveness of the UN in Rwanda in 1994, or currently in Somalia and Syria and many other places, leading to unspeakable atrocities. Setting the story in South African Johannesburg alludes not only to the crimes committed by the Apartheid Regime; it also shows that history is just repeating itself like a vicious circle: according to the film, the South African Apartheid System between humans was just replaced by a new one between humans and aliens. Is it just an inherent part of human nature to always discriminate against an out-group? The aliens are thereby a metaphor for all the excluded and marginalized people worldwide, and very concretely for the hundreds of thousands of Palestinians living in huge refugee camps in Yemen or Jordan with little

4 Why the aliens do not use their weapons for an uprising will remain the central flaw of the movie. 
prospect of a better future. Remarkable in this sense is a scene in the movie of human activists protesting for "human rights" for the intelligent aliens which raises questions about what it means to be human, as well as where humanity begins and ends. Consequently, the genetic humans act inhumanely, whereas the main character, Vikus van der Merwe, after being infected with a virus that transforms him into an alien, appears even more humane in his metamorphosis.

Of crucial importance is also a point which is not even mentioned in the film, but which conveys a hopeless message for humanity in its banality: District 9 lacks the global impact of a possible alien contact which could have at least united the humans and led to the establishment of a common human identity. ${ }^{5}$ Contrary to the utopian setting of Star Trek where the first contact with the Vulcans united the "human race," the alien contact in District 9 is absolutely limited to South Africa. In this country and, by extension, the rest of the world, suppression between humans is going on as ever, independent of the spectacular spaceship hovering above the city of Johannesburg. The direct contact with the alien other has not provoked any effect for a positive development of humanity; on the contrary, it has made humans look all the more brutal and savage. ${ }^{6}$

\section{Conclusion}

This paper argued that boundary management and dealings with otherness were fundamental themes in SF films providing, at the same time, a mirror of our current social and political problematics. As one can see, the analyzed films project our fears into a future or alternative setting where theoretically anything could be possible. However, the films are a critical discourse about our current political reality and problematics against the backdrop of "a new age" dating back to 2000 and the new political global setting after the attacks of 9/11. In Equilibrium we see absolute surveillance in a totalitarian system creating an artificial divide between emotions and rationality. In Code 46 an apparently liberal worldstate has developed but it is one with disturbing totalitarian distortions substituting the national border for an even more precarious genetic one. Children of Men confronts us with a demographic and ecological collapse leading to the breakdown of international cooperation and an

5 Alexander Wendt claims that an alien contact might be a way to develop a common human identity (389).

6 Interesting in this regard is the book by Albert A. Harrison about possible human responses to an alien contact. 
overemphasizing of national borders, while in District 9 a seemingly independent and non-legitimized organization exploits and marginalizes an out-group of aliens.

Each of these films presents a different dystopian setting where questions of human identity and body politics play an important role showing up in the form of current national and international problematics as, for example, total surveillance and segregation. However, these are not only the fears of our current reality, but also those of the human political and social condition in general. We always were and always will be concerned about the other beyond the known border or be afraid of an authority exerting absolute power. In this way, since SF serves as a looking glass magnifying our problems, it invites us to think about and discuss as yet unarticulated issues, making it possible to find ways to deal with real potential problems in the future. Geoffrey Whitehall appropriately summarizes this perspective when describing SF as the "genre of the beyond" (172). Hence, SF enables us as social scientists to think out of the box when discussing current and future challenges initiated by social developments and technological progress. SF can also be an inspiration for policymakers aiming to create a better world by implementing necessary regulations, fighting inequality, and, finally, trying to overcome our real and imagined boundaries.

\section{Works Cited}

Arnswald, Ulrich, and Hans-Peter Schütt. Thomas Morus' Utopia und das Genre der Utopie in der Politischen Philosophie. Karlsruhe: KIT Scientific Publishing, 2010. Print.

Buzan, Barry. "America in Space: The International Relations of Star Trek and Battlestar Galactica." Millennium. Journal of International Studies 39.1 (2010): 175-80. Print.

Children of Men. Dir. Alfonso Cuarón. Perf. Julianne Moore, Clive Owen. Universal Studios, 2006. Film.

Code 46. Dir. Michael Winterbottom. Perf. Samantha Morton, Tim Robbins. BBC, 2003. Film.

District 9. Dir. Neill Blomkamp. Perf. Jason Cope, Sharlto Copley. TriStar Pictures, 2009. Film.

Equilibrium. Dir. Kurt Wimmer. Perf. Christian Bale, Emily Watson. Miramax Films, 2002. Film.

Fukuyama, Francis. The End of History. New York: Routledge, 1992. Print. Grosz, Elizabeth. Space, Time, and Perversion: Essays on the Politics of Bodies. New York: Routledge, 1995. Print. 
Harrison, Albert A. After Contact: The Human Response to Extraterrestrial Life. New York: Perseus, 2002. Print.

Hobsbawm, E. J. Nations and Nationalism since 1780: Programme, Myth, Reality. New York: Cambridge UP, 1992. Print.

Huntington, Samuel P. The Clash of Civilizations and the Remaking of World Order. New York: Simon, 1996. Print.

Kiersey, Nicholas J., and Iver B. Neumann. "Introduction: Circulating on Board the Battlestar." "Battlestar Galactica" and International Relations. Ed. Nicholas J. Kiersey and Iver B. Neumann. New York: Routledge, 2013. 1-17. Print.

Kuhn, Annette, ed. Alien Zone. London: Verso, 1990. Print.

---, ed. Alien Zone II. London: Verso, 1999. Print.

McDermott, Rose. Political Psychology International Relations. Ann Arbor: U of Michigan P, 2004. Print.

Mercer, Jonathan. "Rationality and Psychology in International Politics." International Organizations 59.1 (2005): 77-106. Print.

Neumann, Iver B. "Grab a Phaser, Ambassador: Diplomacy in Star Trek." Millennium. Journal of International Studies 30.3 (2001): 603-24. Print.

Nexon, Daniel H., and Iver B. Neumann. Harry Potter and International Relations. Oxford: Rowman, 2006. Print.

Sontag, Susan. "The Imagination of Disaster." Commentary Magazine 1 Oct.1965. Web. 30 June 2018.

Stein, Janice Gross. "Foreign Policy Decision-making. Rational, Psychological, and Neurological Models." Foreign Policy: Theories, Actors, Cases. Ed. Steve Smith and Tim Dunne. Oxford: Oxford UP, 2008. Print.

Tajfel, Henri. Social Identity and Intergroup Relations. Cambridge: Cambridge UP, 2010. Print.

---. "Social Psychology of Intergroup Relations." Annual Reviere of Psychology 33.1 (1982): 1-39. Print.

---, and John Turner. "The Social Identity Theory of Intergroup Behavior." Psychology of Intergroup Relations. Ed. Stephen Worchel and W. G. Austin. Chicago: Nelson-Hall, 1986. 7-24. Print.

Waltz, Kenneth. Theory of International Politics. New York: McGraw-Hill, 1979. Print.

Weldes, Jutta. "Popular Culture, Science Fiction, and World Politics: Exploring Intertextual Relations.” To Seek Out New Worlds: Science Fiction and World Politics. Ed. Jutta Weldes. New York: Palgrave Macmillan, 2003. 1-20. Print.

Wendt, Alexander. "Collective Identity Formation and the International State." American Political Science Review (1994): 384-96. Print. 
Whitehall, Geoffrey. "The Problem of the 'World and Beyond': Encountering 'the Other' in Science Fiction.” To Seek Out New Worlds: Science Fiction and World Politics. Ed. Jutta Weldes. New York: Palgrave Macmillan, 2003. 169-93. Print.

Isabella Hermann is a political scientist by training. She holds a $\mathrm{PhD}$ in International Relations where she specialized in international respect and status issues using constructivist and discourse analytical research designs. Having always been fascinated by the sociopolitical impact of new technologies, she also started to publish and give talks about science fiction and (global) politics. Right now, technologies such as smart machines, which have formerly been labelled science fiction, are becoming reality-and so are ethical concerns of applying them. Therefore, Isabella Hermann is now a research coordinator of the interdisciplinary research group "Responsibility: Machine Learning and Artificial Intelligence" at the Berlin-Brandenburg Academy of Sciences and Humanities in Berlin. The project explores the ethical challenges regarding AI systems and it will elaborate on recommendations for dealing with the new technologies in a positive way.

isabella_hermann@hotmail.com 